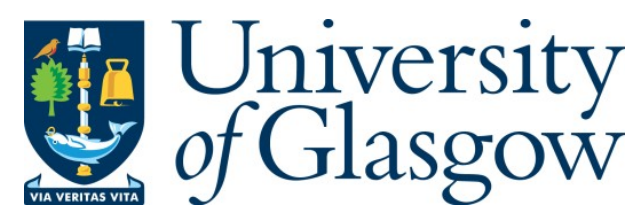

Miao, J. T., and Hall, P. (2014) Optical illusion? The growth and development of the Optics Valley of China. Environment and Planning C: Government and Policy, 32 (5). pp. 863-879. ISSN 0263-774X

Copyright (C) 2013 Pion and its Licensors

http://eprints.gla.ac.uk/98479

Deposited on: 21 October 2014

Enlighten - Research publications by members of the University of Glasgow

http://eprints.gla.ac.uk 


\title{
Optical illusion? The growth and development of the Optics Valley of China
}

\author{
Julie Tian Miao \\ Centre for Housing Research, The Observatory, University of St Andrews, KY16 9LZ, \\ Scotland; e-mail:tm65@st-andrews.ac.uk \\ Peter Hall \\ Bartlett School of Planning, University College London, Wates House, 22 Gordon Street, \\ London WC1H 0QB, England; e-mail: p.hall@ucl.ac.uk \\ Received 25 March 2012; in revised form 28 November 2012; \\ published online 6 September 2013
}

\begin{abstract}
The 'cultivated' nature of the Chinese science parks, against the background of a transitional economy, differentiates them from spontaneous and cooperative Western models, and is a phenomenon deserving close examination. We study the dynamics and features of the so-called Optics Valley of China (OVC) in Hubei, aiming to explore the characteristics of an embryonic local innovation system constructed in a less-favoured region. The results show that institutional factors are the leading forces in a cultivated science park like the OVC. However, along with the shifting focus of the local government, the OVC's industrial scale has remained small and its industrial chain has remained incomplete. Moreover, the lack of trust and interactions between various components in this innovation system has been highly noticeable. All these features may be seen as warnings to the OVC that a revision of this innovation system is needed in order to avoid the fate of becoming an 'optical illusion'.
\end{abstract}

Keywords: innovation system, science parks, China, OVC

\section{Introduction}

The rapid diffusion of information technology after World War II fostered the development of new industrial and innovation hubs - such as Silicon Valley, Route 128, and Cambridge (UK) - emerging outside the established industrial centres (Cook and Joseph, 2001; Hall et al, 1987; Moore and Spires, 1983; Saxenian, 1985). Their outstanding features - the crossfertilisation between universities, research laboratories, and the companies within or in the vicinity of a science park - have served as a prototype for other regions to follow. Although there were only two science parks fifty years ago - the Stanford Research Park in California and the Research Triangle Park in North Carolina - by 1992 there were more than seven hundred worldwide (Kung, 1995, page 63), and their geographical diffusion has quickened during recent years, especially in the Asia-Pacific region.

Available studies on science parks reach differing, even opposing, conclusions. Proponents of science parks point to the significant knowledge spillover effect, facilitated by physical proximity and routinised face-to-face contact (Anselin et al, 1997; Hong, 2008; Storper and Venables, 2003). Sceptics who argue that these are 'high-tech fantasies' (Massey et al, 1992) criticise the 'linear logic' of transferring technology from research institutes (RIs) and higher education institutes (HEIs) to private companies and then the market that underpins the science park model (Felsenstein, 1994; Godin, 2006). For them, the costs of pursuing a 'Silicon Valley dream' by many regions would far exceed any possible gains (Castells and Hall, 1994a; Westhead and Storey, 1994). However, it is argued here that while the general research on innovation has moved far beyond the linear standpoint, studies on science parks 
have not yet escaped from this unidirectional innovation assumption. This research will show that, by replacing the linear view with a systematic and dynamic standpoint, science parks are likely to diversify from each other in their structures and evolutionary trajectories.

The emerging innovation system theory provides just such a systematic toolkit, and science parks will be analysed in this study as potential local innovation systems. On the basis of the roles and relationships of different system components, science parks can be classified into three types - spontaneous, cooperative, and cultivated - each with specific characteristics that will be illustrated in the following section. Chinese science parks fall into the cultivated type due to the dominant role of the governments. Moreover, three features of these implanted innovation systems are noteworthy. First of all, the tasks of Chinese science parks are fundamentally influenced by China's reform process. Conceived under the background of the Cold War in the early 1980s, the priority of these science parks used to be upgrading the technological sophistication of China, but has now shifted to economic reform and a more balanced regional development (interview, officer from the Torch Centre, Ministry of Science and Technology, 20 August 2010). Yet only recently has the importance of linkages between knowledge resources and the private sector been emphasised. The second feature lies in their spatial organisation. Unlike the preference for suburban areas in Western countries (O'Mara, 2005), science parks in China are purposely located inside or adjacent to the metropolitan areas with relatively advanced transport connections and industrial foundations (Torch Center, 2008). Last but not least is arguably the huge heterogeneity of these science parks in different regions, which reflects the economic strength of the host regions and the economic and social compatibility of the science parks with the local structures. What remain unclear, however, are the systematic dynamics and synergies of these implanted innovation systems.

In order to explore further the previously discussed characteristics of the science parks in China, the main questions to be answered in this research are: (1) Compared with Westernstyle science parks, how are science parks planned in China? (2) Regarding their spatial organisation, what are the relations between these cultivated high-tech communities and their host regions? (3) Economically and technologically, what are the linkages between the actors within and beyond a science park?

To resolve these questions, the innovation system literature will be employed in section 2, albeit with the necessary specification to make it more applicable to the science park phenomenon. Following the theoretical construction, the focus of this paper will move on to the general profile of the Chinese science parks (section 3) and then to a case study of the so-called 'Optics Valley of China' (OVC) in Wuhan, Hubei province (section 4). The research methods involved a face-to-face questionnaire survey of the 147 optoelectronic firms on this science park out of the 184 identifiable optoelectronic companies in Hubei. ${ }^{(1)}$ Together with telephone and e-mail surveys, 138 responses were finally received, totalling a high $(80 \%)$ response rate. The methods also involved fifty-five interviews with policy experts from different layers, consultants, and industrial representatives. Here we draw upon selected data from the survey and interviews to tell the story of the OVC - which, as a cultivated cluster of optoelectronic companies, might be more suitably read as a 'political illusion' instead of a real innovative milieu. A short conclusion and reflection on this study in section 5 will end this paper.

(1) The company list was obtained through: (1) the directory of the National Optoelectronics Association, (2) the directory provided on the official website of the OVC, and (3) the directory listed on the official website of the Laser Industry Association of the OVC. Each company was double checked either through their websites or by telephoning. 


\section{A dynamic innovation system and its application to science parks}

Most, if not all, studies of science parks assume that these artificial clusters are built on the logic of a linear model, a term that can be attributed to Bush (1945). As this model assumes an inexorable process of innovation that is not subject to intervention, it alone seems evident to predict the science park practice as a failure (Cooke, 2001; Massey et al, 1992). Yet the dynamic of a real-life science park, it is argued here, is very much determined by its designers and the changing relations between the partners involved. Some researchers have already pointed out that the number of 'second-generation science parks' - those that concentrate on building the systematic synergy - is increasing (Hansson et al, 2005), and their efforts in cultivating entrepreneurship, supporting small and medium enterprises (SMEs), and developing community recognition are significantly extended compared with the science parks built in the 1960s and 1970s (AURP and Battelle, 2007). Therefore, it is necessary to substitute a systematic model for the linear view of innovation, in order to update our understanding of the current science park phenomenon.

The concept of an innovation system is adopted here as a promising analytical toolkit. This theory was first proposed in the 1980s by Lundvall (1985), Freeman (1988), and Nelson (1988), and arguably has become one of the most comprehensive views on the innovation process (Mothe and Paquet, 1998). Straddling the intersection of institutional economics (Radosevic, 2007) and evolutionary economics (Lundvall, 2007), the theory of an innovation system emphasises the role of institutions along the trajectory of technology development, which in turn are embedded within the historical development of a nation or subnation. Knowledge exchange, learning, and networking are the key ideas that are shared by most students in this school.

As an emerging theory, however, the innovation system concept also has deficits that need improvement in order to fulfill its explanatory capability. The first shortcoming lies in the limited attention paid to less-developed regions, where innovation systems are built from scratch on the foundation of relatively backward industry structures. The second weakness is the ambiguity of the growth engine for an innovation system, while too much attention has been paid to the macroconditions of a nation or region (Doloreux and Parto, 2005; Lundvall, 1992; 2007; Radosevic, 2007). Last but not least, the relationship between the national, regional, and local innovation systems is far from clear.

Policies and politics are important considerations for the dynamics of innovation systems, because they are among the main channels through which the institutional environment could influence the core of an innovation system - the companies. Under the umbrella of innovation-promoting policies, the model of science parks has been adopted by increasingly more governments as one route of building their innovation systems from scratch. Although it has been pointed out that these knowledge facilities may not necessarily be the most efficient way of promoting innovations (Castells and Hall, 1994a; Felsenstein, 1994; Grayson, 1993), the science park model could still be seen as a more concrete planning concept compared with the flexible term of 'innovation system'. Therefore, a close monitoring of the genesis and growth of a science park could shed light on the dynamics of an innovation system-a theoretical gap that remains to be filled in the current innovation system theory.

Three factors are of crucial importance for analysing the changing conditions of a system, which are: (1) the leader of this system, (2) the engine for its sustainable growth, and (3) the efficiency of this system to achieve its designed function. On the basis of the combinations of the above factors, we come back to the three types of science parks mentioned previouslyspontaneous, cooperative, and cultivated (table 1) - although there are many more versions along the combination spectrum of these three factors. 
Table 1. The three prototypes of science parks (source: the authors).

\begin{tabular}{lllll}
\hline Type/actors & Enterprises & Governments & HEIs and RIs & Service sectors \\
\hline Spontaneous & take the lead & liberal attitude & $\begin{array}{l}\text { take initiatives to } \\
\text { engage } \\
\text { encouraged or }\end{array}$ & $\begin{array}{l}\text { attracted by the } \\
\text { market potential } \\
\text { encouraged or } \\
\text { voluntarily engage }\end{array}$ \\
Cultivated & attracted in later & take the lead & $\begin{array}{l}\text { supportive from } \\
\text { other actors } \\
\text { the beginning } \\
\text { pushed to engage }\end{array}$ & $\begin{array}{l}\text { lack initiative to } \\
\text { engage }\end{array}$
\end{tabular}

Note: $\mathrm{HEI}=$ higher education institute; RI = research institute.

A spontaneous science park is the archetypal science park associated with such famous names as Silicon Valley (Saxenian, 1985) and Cambridge (Keeble, 1989). The private companies are the leaders of its growth. A reciprocal relationship between the knowledge resources and enterprises, a continuous entrepreneurship spark, and a desire for innovations are the engines for its growth. Although the start of a spontaneous science park can be slow and less noticeable, once it reaches the crucial threshold of an industrial mass, other sectors will follow and build on the existing synergy of this innovation system, making it highly efficient in adopting and innovating. Therefore, the dynamic of a spontaneous science park resembles the typical 'S-shaped' life cycle of a cluster (Audretsch and Feldman, 1996; Feldman and Francis, 2001; Press, 2006). A cooperative science park, on the other hand, is typical in many developmental states, in which more than one partner jointly takes the initiatives, and a strong commitment of the state as well as other innovation components serves as the engine for its growth. The cooperative science park starts with a stronger systematic synergy, which, quite possibly, also increases steadily as more partners are attracted in. The last category, the cultivated science park, is popular in developing countries as a result of the political desire to mimic the above two types of innovation systems. The government is the leader as well as the engine for its development. By providing incentive policies - such as favourable taxation, cheap land, and grants - other sectors may slowly join in. Depending on the interactions of these actors as well as the commitment and effort of the government, a cultivated science park might turn out to be a functioned innovation system as well, or just degrade to another manufacturing base (see figure 1).

Science parks in China should be classified as the cultivated type due to the decisive role of the governments. The cultivated model is shown here against the context of a state moving from 'planned economy' to 'planned market', and now 'market economy with Chinese characteristics' (John and Barry, 1992; Naughton, 1990). Previously, firms in China were separated from RIs and HEIs by following the practice of the former Soviet Union (OECD, 2008), which resulted in a lack of cooperate experience and mutual trust with each other until now. Moreover, the industry layout in China can still be shifted by state interventions and industrial policies (Fan, 1995; Jefferson et al, 2003). Therefore, the barriers to the formation

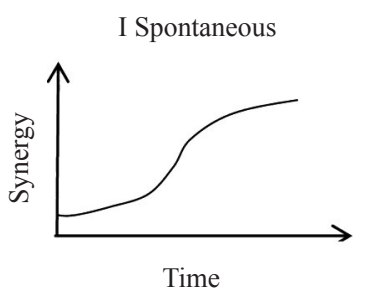

II Cooperative

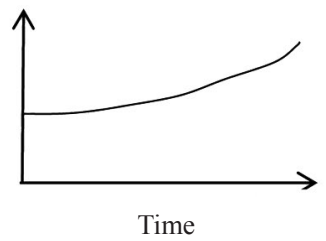

III Cultivated

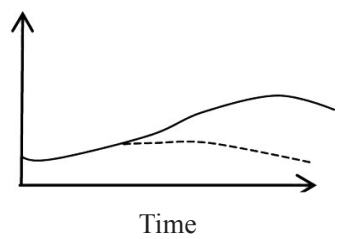

Figure 1. Development trajectories of the three types of science parks (source: the authors). 
of spontaneous-type or cooperative-type science parks are high in this country. Nevertheless, the cultivated science parks provide a promising 'short-cut' for China to get on board the 'high-tech train'. In order to illustrate the dynamics of these implanted innovation systems and their compatibilities with the local economic and institutional structures, the features of the Chinese science parks in general and the OVC in particular will be discussed in the following sections.

\section{Science parks in China}

\subsection{What, where, and why are the Chinese science parks?}

The definitions, organisations, and targets of science parks differ significantly in different regions and states (Phillimore and Joseph, 2003), and this complexity is arguably reflected nowhere more obviously in a single country than in China because of its sheer size. The Torch Center, established in 1986 under the Ministry of Science and Technology (MOST, 2004), is the management authority of the national-level science parks. It defines the Chinese science parks as:

(1) a base to develop high and new technology industries;

(2) a radiator for diffusing high technologies and products to traditional industries;

(3) an experimental zone for institutional reform and innovation;

(4) a demonstration centre for linking science and technology (S\&T) with industries;

(5) a new community that embodies modern socialism;

(6) a school for cultivating high-tech enterprises and entrepreneurs;

(7) an exhibition window to other countries (see also Torch Center, 2009).

The first national-level science park, acknowledged in 1988, was Zhongguancun Hightech Zone in Beijing. However, a consensus on the value of science parks at the top level was reached relatively late in 1991, when twenty-six local initiatives were upgraded as national-level science parks. By 2011, there were eighty-four national-level science parks scattered all over China ${ }^{(2)}$ (Xinhua News Agency, 2010; Zhongliang, 2011). Three types of metropolitan areas are preferred by the central government to host a science park, which are: (1) core cities with better knowledge resources and industrial foundations; (2) coastal cities that opened up earlier and thus have a better representation of multinational corporations; and (3) traditional military bases (Torch Center, 2008) (figure 2). Therefore, it seems that science parks in China are posited on the foundations of more advanced regional innovation systems, which contrasts clearly to the prototype suburban science parks in Western countries (Luger and Goldstein, 1991).

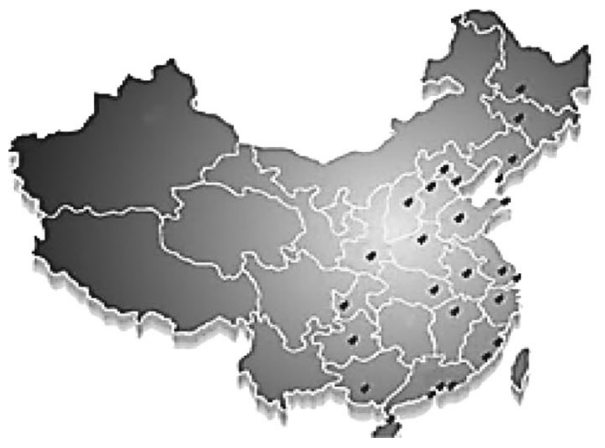

(a)

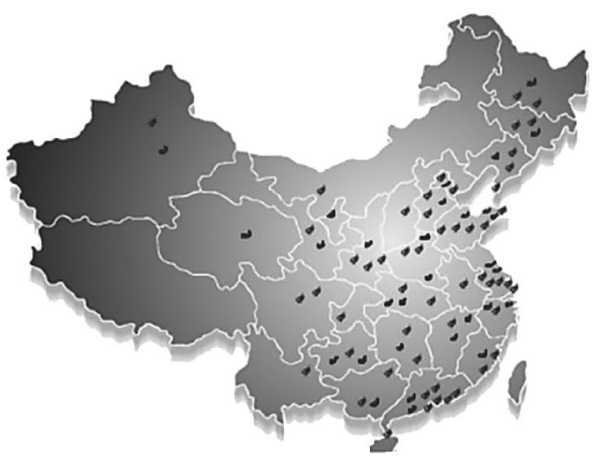

(b)

Figure 2. The distribution of state-level science parks in China in (a) 1991 and (b) 2010 (source: Torch Center, 2009).

${ }^{(2)}$ All provinces except Tibet had at least one national-level science park by 2011. 


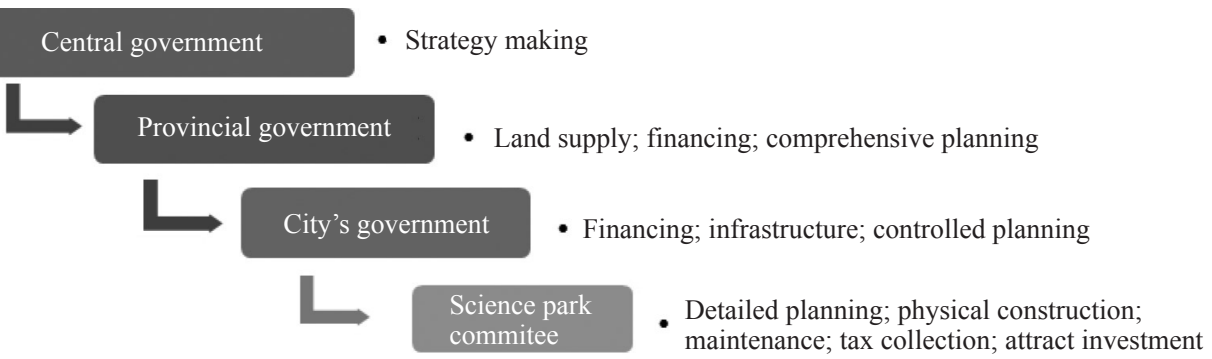

Figure 3. The bureaucratic hierarchies of the science park authorities and their responsibilities (source: the authors).

Although national-level science parks were generally built upon the most-developed metropolitan cities within a region, the huge urbanisation and modernisation impulses brought by science parks have nevertheless triggered the enthusiasm of the regional and local governments, who are either directly or indirectly engaged in the construction of thousands of various types of science parks (Haifeng, 2005). By 2009, for example, there were 129 provincial-level science parks sponsored by the regional governments (Baidu 2009). In Hubei alone there were 124 properties that were labelled as science parks in 2008 (Statistics Bureau of Hubei, 2009).

This nationwide popularity of science parks in China brings into question the redistribution of power between the central and the regional governments. According to an officer from the Torch Center (interview, 20 August 2010), the role of the central government in the construction of science parks is now confined to making guidelines and picking winners in national S\&T projects. The local governments, on the other hand, control the fixed assets, finance, administration, and infrastructure supply, and thus the practical power over the science parks they host. What they value from the central government are the brands and honours brought by winning a national S\&T project or being awarded a national title (figure 3). Therefore, this decentralised administrative power of science parks in China helps to embed these potential local innovation systems into their regional innovation systems from the beginning.

This intertwined relationship between a region's institutional environment and its science parks might further lead to the synchronisation of its economic structures. Although one of the defined targets for China's science parks, as mentioned earlier, is to diffuse high technologies to traditional industries and thus unlock or update a region's backward industrial structure, the reality in many regions is that their traditional industries (many of which are not regarded as high-tech ones) have been penetrating into their hosted science parks, and ironically stand besides the high-tech sectors purposely cultivated by the central government. For example, the science park in Liuzhou City was overwhelmingly occupied by suppliers to the leading local revenue generator, Dongfeng Automobile, which was located outside the park (interview, Officer of the Science and Technology Bureau of Liuzhou, Guangxi Province, 19 August 2010). In the OVC an iron industry park, a dockyard industry park, and an automobile industry park were gradually set up besides the earlier established optoelectronic industry parks (WEHDZ, 2005), with the former all serving the region's traditionally competitive industries. In the following subsection we will illustrate the dynamics of the OVC in more detail.

\subsection{What, where, and how is the OVC?}

The OVC is an advertising brand for a national-level science park called the 'East Lake High-tech Development Zone' in Wuhan, Hubei Province. The construction of the first National Optoelectronic Industry Base here in 2001 was widely regarded as the justification 
for this nickname (interview, professor from Huazhong Science and Technology University, 12 August 2010). As indicated by this title, the OVC emerged through focusing on the optoelectronic industry. Now it has many leading domestic companies in this sector-such as Fiber Home (2011), which used to be the leading research institution in China focused on optoelectronic technologies, and Yangtze Optical Fibre and Cable Company Ltd, which was number one in fibre manufacturing capabilities worldwide by 2010 (Shangmin, 2010).

Its competitive optoelectronic industry makes the OVC stand out in its host region, Hubei Province, which is traditionally a heavy manufacturing industry base in China. Hubei's well-established industries include automobile, shipbuilding, and iron and steel making (Changlin, 2008). However, both the region and its cities have been suffering from the concurrent industrial restructuring and the unbalanced regional development strategy of Beijing since the 1980s. A large number of state-owned factories in Hubei went bankrupt between the 1980s and the 1990s, and this region was burdened with a higher than the national average unemployment rate for the past decade (National Research Database Center, 2011). Therefore, the case of the OVC is unique as a carefully cultivated high-tech cluster amidst an ocean of heavy industries, especially when the OVC has beaten dozens of other metropolitan cities in the reputation battle for the brand of Optics Valley, ${ }^{(3)}$ and was frequently referred to as one of the most well-known optoelectronic industry bases in China by our interviewees.

Like many other science parks in China, the OVC is also a reform experiment of the open-up policy and economic reform in Hubei since the mid-1980s. Its development has undergone four stages signalled by the upgrading of its political importance (table 2).

The original boundary of the OVC was decided by the then National Science Committee in 1991, ranging from the riverbank of the Yangtze River on its left to the Wuhan Post and Telecommunication Research Institute and Huazhong University of Science and Technology at its right-hand corner. It covered a total area of $43 \mathrm{~km}^{2}$, of which only $24 \mathrm{~km}^{2}$ was developable.

Pushed by the increasing domestic requirement for optoelectronic products, the reform of many local research institutes into companies, as well as the preferential policies offered by the local government, the number of registered on-park companies grew from 124 in 1991 to 2194 in 2009 (see figure 4). This growing number of companies in turn put pressure on the land availability of the OVC. Therefore, since the late 1990s the coverage of the OVC has been moved southeast away from the built-up areas to undeveloped land through its successive boundary expansions. In 1996 the city's government decided to entrust four villages from Hongshang District to the OVC. In 1999 the concept of a 'Wuhan technology new town' was proposed, which in reality provided planning permission for the OVC to further acquire the undeveloped land. In May 2000 the boundary of the OVC was extended southward to include six villages from Jiangxia District (People's Government of Wuhan, 2011; Wuhan Party History Research Centre, 2009). In 2001 thirteen villages from Hongshan and Jiangxia Districts were entrusted to the OVC (Baidu 2011a). In 2008 eleven villages were delegated to the $\mathrm{OVC}$, extending its total area to $221 \mathrm{~km}^{2}$. The latest and largest acquisition of $296.2 \mathrm{~km}^{2}$ of land happened in May 2010, soon after the OVC was given the title of the second national self-innovation model zone. This expansion stretched the OVC's coverage to $518 \mathrm{~km}^{2}$ (Baidu 2011b), twelve times its original area (figure 5). However, the physical expansion of the OVC does not seem to stop here. In August 2010 the site for the so-called 'East Lake future technology town' was decided to be on the east of the OVC, covering

(3) It was reported that by 2009 there were over sixteen science parks in China, which had optoelectronics as one of their targeted industries, and more than ten referred to themselves as some sort of 'optics valley' (Fangling, 2005; Junpeng, 2009; Sohu, 2001). 
Table 2. Brief history and development stages of the Optics Valley of China (OVC) (source: Chun, 2011; OVC, 2009; 2010a; People's Government of Wuhan, 2011; Wuhan Party History Research Centre, 2009; and personal interviews with the Chief Director of the Strategy Research Institute of the OVC, 10 August 2010, the Deputy Director of the Economic Development Bureau of the OVC, 27 July 2010, and the Technical Instructor of the National Optical Laboratory, 12 August 2010).

\begin{tabular}{|c|c|c|c|}
\hline Stage & Milestone & Crucial factors & Achievements \\
\hline $\begin{array}{l}\text { I } \\
(1984-91)\end{array}$ & $\begin{array}{l}\text { East Lake } \\
\text { knowledge- } \\
\text { intensive zone } \\
\text { established in } \\
1988\end{array}$ & $\begin{array}{l}\text { (1) how to promote high-tech } \\
\text { industries was a nationwide hot } \\
\text { topic; } \\
\text { (2) Deng and Hu (then } \\
\text { the General Secretary of } \\
\text { the Chinese Community } \\
\text { Party Central Committee) } \\
\text { strongly supported R\&D } \\
\text { commercialisation; } \\
\text { (3) the son of Hu crucially } \\
\text { contributed to the formation of } \\
\text { this knowledge-intensive zone } \\
\text { when he worked there }\end{array}$ & $\begin{array}{l}\text { (1) planning and management } \\
\text { office was established in 1984; } \\
\text { (2) one of the five chosen } \\
\text { science park pilots in China in } \\
\text { 1985; } \\
\text { (3) China's first incubator was } \\
\text { established here in 1987; } \\
\text { (4) became a member of the } \\
\text { International Association of } \\
\text { Science Parks in } 1990\end{array}$ \\
\hline $\begin{array}{l}\text { II } \\
\text { (1991-2001) }\end{array}$ & $\begin{array}{l}\text { acknowledged as } \\
\text { a national-level } \\
\text { science park in } \\
1991\end{array}$ & $\begin{array}{l}\text { (1) 'South-tour' of Deng freed } \\
\text { people's mind on doctrine } \\
\text { conflicts and reoriented the } \\
\text { reform direction; } \\
\text { (2) industry restructuring } \\
\text { of Wuhan to high-tech, } \\
\text { automobile, commercial, and } \\
\text { iron industries }\end{array}$ & $\begin{array}{l}\text { (1) regulations of Wuhan } \\
\text { East Lake High-tech Industry } \\
\text { Development Zone published } \\
\text { in 1994; } \\
\text { (2) first boundary adjustment } \\
\text { in } 1996\end{array}$ \\
\hline $\begin{array}{l}\text { III } \\
(2001-09)\end{array}$ & $\begin{array}{l}\text { acknowledged } \\
\text { as a national } \\
\text { optoelectronic } \\
\text { industry base in } \\
2001\end{array}$ & $\begin{array}{l}\text { (1) the name of the OVC was } \\
\text { conceived at grassroots level; } \\
\text { (2) quick reaction and } \\
\text { painstaking effort of the local } \\
\text { authorities to promote the } \\
\text { brand of the OVC }\end{array}$ & $\begin{array}{l}\text { (1) large-scale physical } \\
\text { construction started to cater } \\
\text { for the 'technology } \\
\text { new town'; } \\
\text { (2) attracting foreign } \\
\text { investment gained importance; } \\
\text { (3) strong advertising through } \\
\text { the 'exhibition economy' }\end{array}$ \\
\hline $\begin{array}{l}\text { IV } \\
\text { (2009- } \\
\text { present) }\end{array}$ & $\begin{array}{l}\text { upgraded as a self- } \\
\text { innovation model } \\
\text { zone in } \\
2009\end{array}$ & $\begin{array}{l}\text { (1) successive lobbying of the } \\
\text { local authorities for this title; } \\
\text { (2) central China's backward } \\
\text { situation gained the attention } \\
\text { of Beijing }\end{array}$ & $\begin{array}{l}\text { (1) the largest boundary } \\
\text { adjustment in } 2008 \text {; } \\
\text { (2) fourteen reform and } \\
\text { preferential policies were } \\
\text { announced in } 2010\end{array}$ \\
\hline
\end{tabular}

an area of $66.8 \mathrm{~km}^{2}$ until reaching the east boundary of Wuhan. Its construction standard was targeted at 'international first class', and its catered activities were to be confined to developmental research (WEHDZ, 2010).

These successive physical expansions were, however, only partly pushed by the growing demand from the private sector. The shifting focus of the local government from industry development to real-estate construction arguably counted here as well. According to its newly elected governmental authority in the new century, the development of the OVC should depend on industrial development, on the one hand, and on infrastructure construction, on the other. While the former is the 'blood' of a science park, the latter is nevertheless the 'vein' and should enjoy equal priority (Rui, 2001). As a result, only $22.95 \%$ of the total construction land was reserved for industrial usage, according to the OVC's 2006 Comprehensive Plan, while residential usage accounted for $19.67 \%$ and public facilities and 


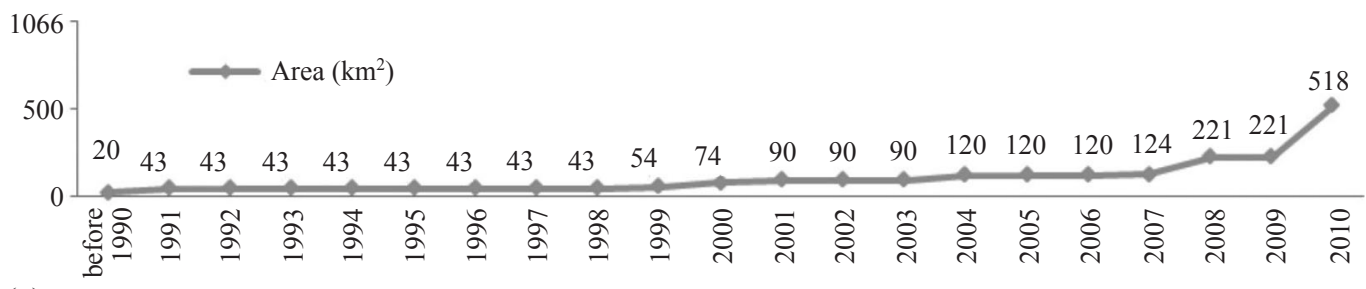

(a)

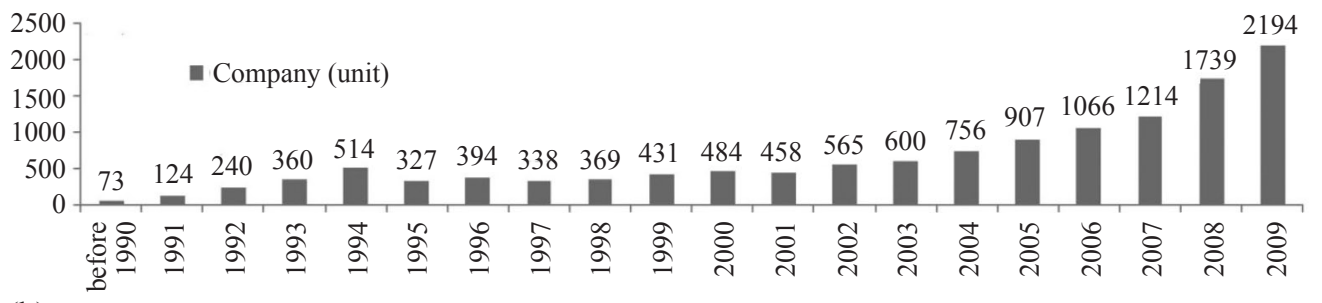

(b)

Notes: Data for the coverage of the OVC were from Wuhan Party History Research Centre (2009); Baidu (2011a; 2011b), and People's Government of Wuhan (2011); numbers of registered companies in the OVC were from Guang (1995), Wan (1991), Honggu (1993), and Shanla $(1993 ; 1994)$, for the time period before 1995, and from the Torch Center (2001) and Science and Technology Statistics of China (STS, 2011) for afterwards.

Figure 4. The (a) coverage and (b) registered number of companies in the Optics Valley of China (OVC).

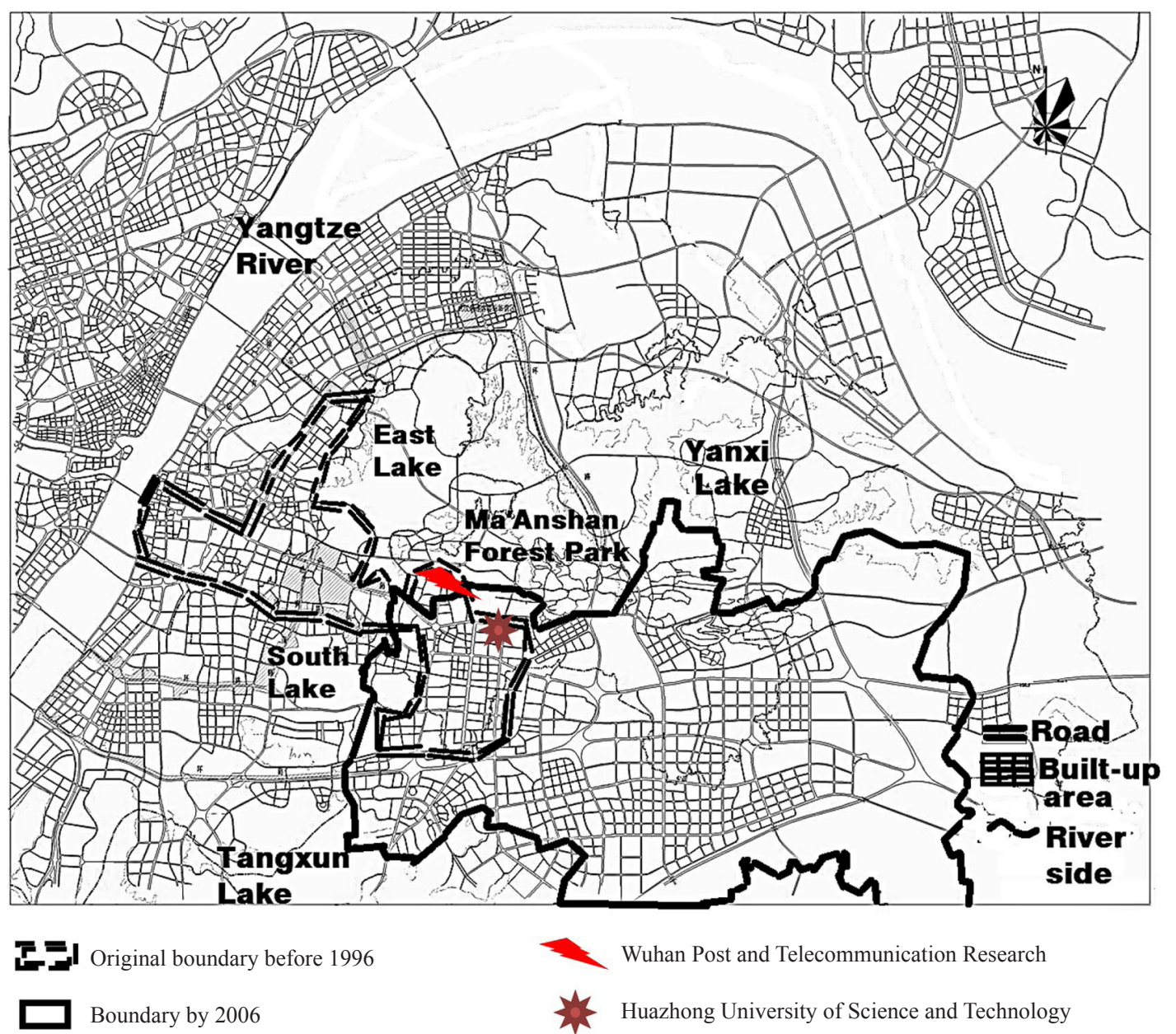

Figure 5. [In colour online.] Original and current boundaries of the Optics Valley of China (source: OVC, 2010a; People's Government of Wuhan, 2011). 
utilities, such as the four major commercial centres, accounted for 23.97\% (OVC, 2010b). By contrast, the Director from the Urban Planning Bureau of Wuhan remarked that:

"The management authority of OVC started from industrial development and research commercialisation at the beginning. However, since the real-estate development was more effective in increasing the city's revenue in a short time and in boosting the image of Wuhan in the long run, its focus has gradually shifted to sell land to developers or directly engaged in real-estate development" (interviewed on 13 August 2010).

So it seems that the local authorities have been increasingly interested in using the brand of Optics Valley as a 'political illusion' to cover their underlying basic desire for revenue increase. The initial targets on leveraging the innovation capabilities of the companies and cultivating the innovation synergy of the whole system, however, have to compete with many short-term revenue generators. This shifting political focus, coming before the OVC could cultivate a substantial system synergy, is arguably pushing this cultivated innovation system down the efficiency slope in the long run (figure 1), as the orientation of the institutional factors would direct the growth of a cultivated innovation system significantly.

\section{System synergies in the OVC}

Looking beyond the OVC's impressive physical expansion and infrastructure improvement, in this section we will explore deeper into this cultivated innovation system on both its traded and untraded synergies.

\subsection{Traded interdependencies of the OVC}

The geographical layout of a company's input-output relation is crucial for analysing the company's local embeddedness, as many untraded interdependencies between companies are partly established and partly sustained by their business linkages. According to Hendry and his colleagues $(1999 ; 2000 ; 2003)$, an early international engagement is a noticeable feature of the optoelectronic companies due to the way its market is formed. This tight global linkage, on the other hand, is more beneficial if derived from the endogenous companies, as Phelps $(2008 ; 2009)$ rightly pointed out that the overreliance on foreign investment in some declining industrial regions in UK could result in only a 'capture' of the local resources. Therefore a balanced local-international input and output distribution is arguably no less important than the absolute number of companies a region has.

In order to identify the geographical distribution of the optoelectronic companies' inputoutput linkages, the surveyed companies in the OVC were asked to estimate the ratios of their input and market shares on different geographical levels. Figure 6 summarises companies' current input-output distributions.

Several features of the surveyed companies' input-output distributions are worth noting. First of all, the local companies in the OVC were largely relying on other regions of China for both input and sales. This in turn was arguably derived from two main reasons.

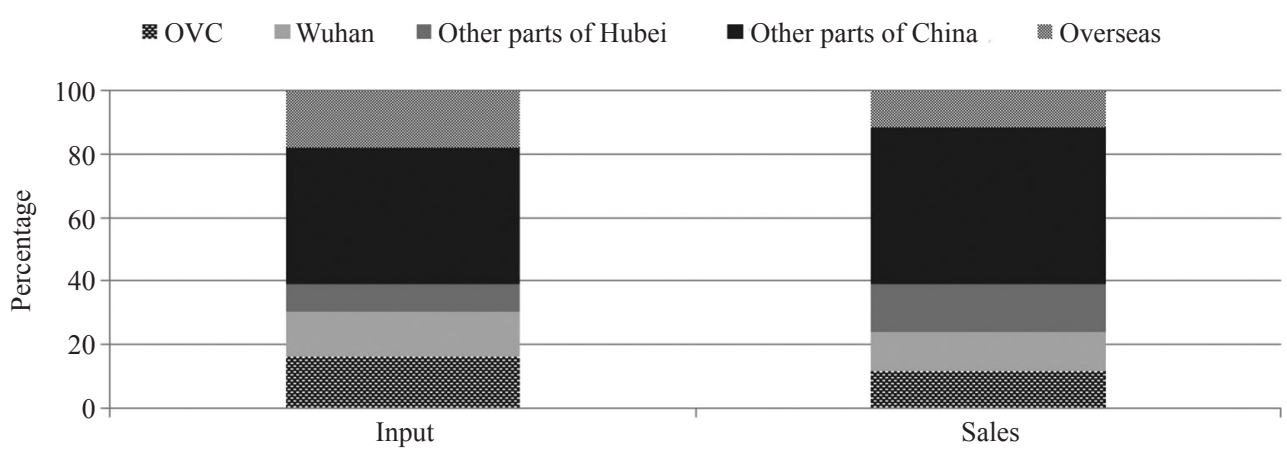

Figure 6. Geographical distributions of companies' input-output linkages (source: the authors). 
First, the OVC's industry scale was still too small to attract a reasonable agglomeration of specialised suppliers. The OVC was supposed to concentrate solely on optoelectronics and its related industries. However, its industrial boundary was extended constantly to cover not only the optoelectronic information industry $(41.25 \%$ of the total industry revenue in 2006 , amounting to 35.1 billion RMB) but also the mechanical and electrical integration (16.43\%), environmental protection (9.65\%), new materials and energy $(9.34 \%)$, and bioengineering and new medicine $(6.23 \%)$ (OVC, 2007). This diversified industry structure is, on one hand, purposely cultivated by the local authorities, as we were told that "the emphasis of our Optics Valley lies in the 'valley' but not the 'optics' now" (interview, Officer of the Economic Development Bureau of the OVC, 28 July 2010). On the other hand, the region's established economic structure has penetrated into this enclave, as shown by the shrinking share of the optoelectronic industry from $41.25 \%$ in 2006 , to $38.22 \%$ in 2007 , and to $37.5 \%$ in 2008 , as well as the growing presence of the mechanical engineering and automobile industries in the OVC (2007; 2011a; 2011b), which are well-established industries in Hubei and Wuhan. This diversified industry structure might be justified by the 'fusion' nature of the optoelectronic technology (Hendry and Brown, 2006), yet it also casts doubt on the OVC's commitment towards industry specification. ${ }^{(4)}$ In comparison, other optoelectronic industrial bases in China have assembled a much more impressive industrial mass. Zhongguancun High-tech Zone in Beijing, for example, had achieved 398.2 billion YMB revenue in 2006 by its electronic industry, among which the optoelectronic-related sectors accounted for $15-20 \%$, or 59.7 billion to 79.6 billion YMB, respectively (Zhongguancun Science Park, 2010). The OVC's lack of success until now in unlocking the heavy industrial structure of its host region echoes the findings by Castells and Hall (1994b) on technocities, and both show the difficulty of cultivating an innovation system within a short time span. In the case of the OVC, however, its soaring revenue increase has casted doubt on the deeper issue of its economic structure and compatibility.

The second reason for the large share of other regions in the surveyed companies' inputoutput network would be attributed to the incomplete optoelectronic industry structure of the $\mathrm{OVC}$ at the time of writing. For example, it was widely acknowledged by our interviewees that the OVC is highly competitive in optical communication and laser sectors, but in all the other optoelectronic sectors the OVC holds no competitive advantages in its technological foundation or in the number of companies (interviews, Secretaries of the National Optical Electronic Association, 28 July 2010, and Director of the OVC Strategy Research Institute, 29 June 2010 and 10 August 2010). What is more, the lack of specialised suppliers and ancillary sector for the local optoelectronic industry was criticised by all interviewees from the private sector: more than often, companies here had to import the most basic moulds from the coastal regions such as Zhenjiang and Guangzhou. In order to overcome the defective industrial chain, the local large companies, such as FibreHome, opted for an integrated organisational structure and in-house R\&D through mergers and joint ventures (interview, Director of Fibre Home, 8 July 2010). The large numbers of SMEs, on the other hand, were gradually marginalised in this local innovation system, which were degraded into assembly factories for companies in other regions, and had to compete fiercely for contracts in the domestic market.

Another feature that emerged from the survey was the unbalance between the endogenous forces and the exogenous linkages identifiable in the OVC. As informed by the Director of the OVC Strategy Research Institutions, endogenous companies were and continuously are the backbone of the OVC (interviewed on 10 August 2010). However, these homegrown enterprises' international linkages were marginal. Among the surveyed companies, for example, it was found that only $17.7 \%$ of companies' input and $11.6 \%$ of their sales were

(4) Our argument here is that the size and scale of the OVC are too small compared with the metropolitan city of Wuhan or Hubei Province to support a highly diversified industrial structure. 
secured from overseas' markets. In comparison, the optoelectronic companies surveyed by Hendry et al (2000, page 136) — in six regions of the UK, the USA, and Germany - had $30-45 \%$ of their sales revenue coming from the international market, and $30-80 \%$ of supplies sourced internationally. This contradiction could be partly explained by the stricter trading policies of Western countries towards China in some strategic sectors. The laser sector, one of the most competitive sectors of the OVC, is just a case in point. It was mentioned that the aim of the USA was to "impede China's technology advance in laser industry at least twenty years lagging behind America." What is more, the market barrier set by these developed countries was high, making export laser products extremely difficult for Chinese companies (interview, sales manager of a laser company, 28 July 2010). The reality now in the OVC is the limited 'window of opportunities' for companies to leap forward internationally (Perez and Soete, 1988). On the other hand, it was also found that the OVC's international linkages were weak, even benchmarked against the national average. For example, it was noticed that China's export of electronic and communication equipment accounted for $60.5 \%$ of this sector's total sales in 2008. The export of optoelectronic devices and other electronic devices accounted for $66.8 \%$ of this sector's total sales (Statistics Bureau of China, 2009). This gap between the OVC and the national average, we argue, should be largely attributed to the slow opening-up process of Central China. All in all, it seems that the OVC represents another case that confirms Wei's (2010) formulation of the Sunan model, which invalidates both the new regionalism and the global production network perspectives. Therefore, studies of the cultivated science parks in China require a deep understanding of this country and its regions' special backgrounds.

\subsection{Untraded interdependencies of the OVC}

The weak input-output linkages among the local optoelectronic companies identified above, however, might not necessarily predict a gloomy future for the OVC, if its institutional environment works proactively towards cultivating a system synergy. Nevertheless, the shifted development focus of the local government has already left a question mark on its orientation. Therefore, what matters now is the relationship between the private sector and the local knowledge institutions, on which a potential system synergy within the optoelectronic sector will depend.

No traceable formal and long-term cooperation could be readily identified during the life trajectory of the OVC, a problem that largely remained at the time of writing, which was shown by our survey and interview results. More specifically, companies were first asked to rank the relative importance of different actors towards their innovation activities on a five-point scale ( $0=$ 'not important at all'; $4=$ 'very important'). As it turned out, the local knowledge institutions were ranked as 'just so-so' (average ranking 2.02), and the public organisations were ranked as 'not so important' (average ranking 1.65). Following Vedovello (1997; 2000), the format and significance of different interaction channels between companies and knowledge institutions were explored in more detail. Companies were asked by a follow-on question about the relative importance of different interaction formats with the local knowledge institutions, and the results are presented in figure 7.

It is obvious from figure 7 that while the role of informal interactions, such as personal contact (ranked at 2.03) and employing part-time staff (ranked at 2.01), were modestly acknowledged by the surveyed firms, the more formal connections, such as R\&D cooperation and R\&D subcontracting, were not so well recognised (ranked at 1.86 and 1.29 on average, respectively). Furthermore, some interviewees even had a negative impression of RIs and HEIs in general, saying that "the moral standards of HEIs are now declining in China, and they are just places for cheating" (interview, sales manager of an optoelectronics company, 15 July 2010), and that "it will take us at least ten more years to commercialise the R\&D results from the laboratories" (interview, CEO of a laser company, 9 July 2010). 


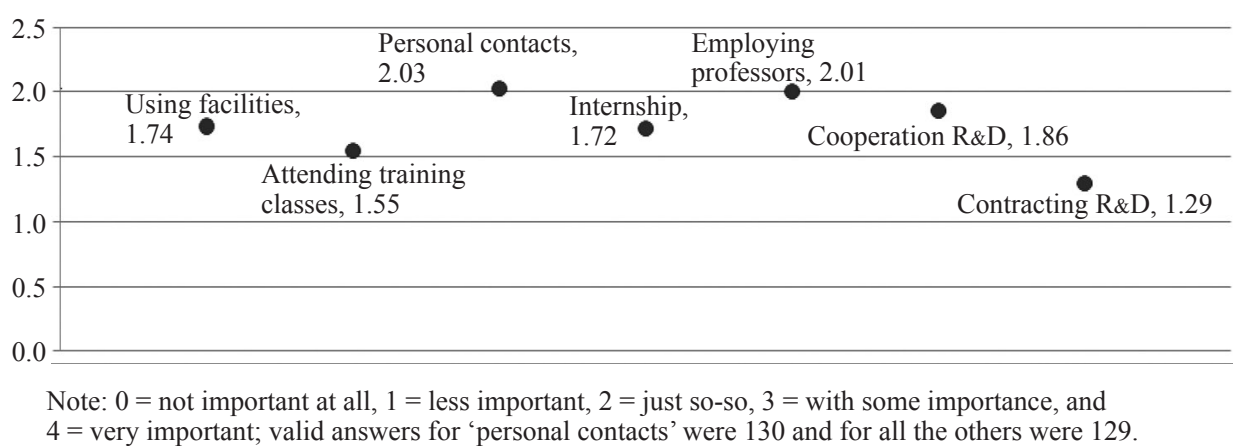

Figure 7. Importance of different interaction formats with local higher education institutions (source: the authors).

This weaker formal interaction between the knowledge institutions and companies identified by the current research is in the same vein as in Vedovello's (1997; 2000). The undamental difference between our study on the OVC and Vedovello's on the Surrey Research Park is the generally low ranking for the knowledge institutes by the surveyed companies. This weak industry-research linkage was partly inherited from the Soviet-style system, in which industry, education, and research were separated from each other. Along with China's reform in the S\&T domain, the segmentation between these different spheres has been reduced significantly, especially in the coastal region, but may not be so obvious in the hinterland. For example, the high-tech zones in the coastal region arguably resemble the cooperative science parks on many standards, as they benefitted the earliest and the most comprehensively from China's reforms (Wei and Leung, 2005). Central China, on the other hand, was experiencing some kinds of 'transforming pains', which meant that its institutional atmosphere was somewhere between the market economy and the rigid socialistic economy. While there were increasing liberalities learnt from the West, they nevertheless rubbed up against the persisting bureaucratic culture (interview, sales manager of a laser company, 28 July 2010). What this struggle leads to, as is obvious here, could either be a blessing or just another curse of the OVC being degraded into an 'optical illusion'.

\section{Conclusion}

The foregoing discussion on China's science park practice in general, and the OVC in particular, can hopefully help to shape answers to the three questions raised at the beginning of the paper. Although similarities could be identified between China and many other developing states on the strong political interventions towards their science parks' development, the fundamental difference, as pointed out repeatedly in the discussion, is the reforming backdrop of China in both its economic and institutional domains. This wider background is reflected by the genesis, growth, and the emerging synergy, if any, of its science parks.

The OVC, for example, was planted top down by the central government. A growing concern about high-tech competition from Western countries first alerted the top party leaders. Then some influential political and academic elites from Hubei handpicked the OVC as a pilot, and tried to motivate other actors to join in its construction. Starting as a reform platform that embedded in a region with relatively backward economic infrastructure, the embryo of the OVC featured an absence of industrial focus and a slow physical construction. It was the gradually released market potential of the optoelectronic industry, and the awareness of this potential by the local governments, that reoriented this cultivated science park towards this particular high-tech sector.

The growth of China's science parks and their spatial organisation are also influenced by China's reform process. Urbanisation, industrialisation, and modernisation are the principal 
targets for Chinese science parks, rather than decentralisation and reindustrialisation. The practical management powers are, on the other hand, decentralised to the regional and local governments, which secures a deeper institutional embeddedness of these implanted innovation systems with the host regions. Regarding their economic contribution, however, the case of the OVC tells a controversial story: most of the optoelectronic companies' input and output has been sourced from other regions in China, which resulted from the incomplete local industrial chain, on one hand, and the negligible cooperation between large companies and the SMEs and between the private sector and the knowledge institutions, on the other hand. Moreover, the role of the OVC as the regional hub on the international value chain is far from established. Conversely, the traditional competitive industries of the region, many of which are not commonly regarded as high-tech ones, are penetrating into this implanted innovation system, a pattern that is facilitated by the shifting focus of the management authority of the OVC towards maximising its revenue.

Regarding the interactions between the private sector and the local knowledge resources, it has been found that the systematic synergy of the OVC is still fragile after almost three decades' growth. The 'dual-track' system that separates research from industry still lingers here, because no serious effort has ever been made before to have these two sectors talking to each other. In addition, the most competitive RIs and HEIs in the OVC seem to prefer commercialising their R\&D in-house, partly pushed by cuts in public funds and partly encouraged by the commercialisation-oriented S\&T reform in China. The division between various innovation partners is still fundamental even today; therefore, it is plausible to say that only the governments have the enabling power to glue the different innovation components together and smooth the system's operation. However, the institutional sector of the OVC has now been undergoing some kinds of transforming pains, and thus whether it can emerge as an innovation hub and revitalise the whole region, or just fall into the trap of 'optical illusion' as time goes by, will depend to a significant degree on the direction and speed of the ongoing economic and institutional reform in the region and in China as a whole. Moreover, what changes would be brought by this reform process to the OVC's international linkage is also an interesting question that deserves follow-on research.

\section{References}

Anselin L, Varga A, Acs Z, 1997, "Local geographic spillovers between university research and high technology innovations" Journal of Urban Economics 42 422-448

Audretsch D B, Feldman M P, 1996, "Innovative clusters and the industry life cycle" Review of Industrial Organization 11 253-273

AURP, Battelle, 2007, "Characteristics and trends in North American research parks: 21st century directions", Battelle Technology Partnership Practice and Association of University Research Parks, Tucson, AZ

Baidu 2009, "How many provincial science parks are there in China?", http://zhidao.baidu.com/question/92456456.html

Baidu 2011a, "Optical Valley of China", http://baike.baidu.com/view/633053.html

Baidu 2011b, "Optics Valley of China: development history", http://baike.baidu.com/ view/22910.html

Bush V, 1945 Science: The Endless Frontier (Ayer Co, North Stratford, NH)

Castells M, Hall P, 1994a Technopoles of the World: The Making of Twenty-first-century Industrial Complexes (Routledge, London)

Castells M, Hall P, 1994b, "Technology parks: inducing the new industrial space", in Technopoles of the World: The Making of Twenty-first-century Industrial Complexes Eds M Castells, P Hall (Routledge, London) pp 84-111

Changlin M, 2008, "Historical investigation of the industrial development strategy of Hubei", in Historical Investigation of the Economic Development Strategies of Hubei in the 30 Years after Opening-up Eds M Changlin, G Jie, G Changmin, Q Zunwen, T Xin'an, X Yuming (Hubei Yangtze Publisher Group, Wuhan) pp 32-50 
Chun W, 2011, "From revolution to develop industry: Hubei witness the transformation of the Party", Jingchu Net, http://www.cnhubei.com/xwzt/2011/jd90/ds/ dszs/201105/t1691390.shtml

Cook I, Joseph R, 2001, "Rethinking Silicon Valley: new perspectives on regional development" Prometheus 19 377-393

Cooke P, 2001, "From technopoles to regional innovation systems: the evolution of localised technology development policy" Canadian Journal of Regional Science 24 21-40

Doloreux D, Parto S, 2005, "Regional innovation systems: current discourse and unresolved issues" Technology in Society 27 133-153

Fan C C, 1995, "Of belts and ladders: state policy and uneven regional development in post-Mao China" Annals of the Association of American Geographers 85 432-449

Fangling Z, 2005, "Five topics around the optoelectronics industry of China" Xinhua News http://news.xinhuanet.com/expo/2005-12-23/content_3958992.htm

Feldman M P, Francis J, 2001, "Entrepreneurs and the formation of industrial clusters", paper presented at the Conference on Complexity and Industrial Clusters, 'Dynamics, Models, National Cases', 19-20 June, Milan, Italy, http://www.cs.jhu.edu/ mfeldman/Feldman\%20-EFIC.pdf

Felsenstein D, 1994, “University-related science parks: 'seedbeds' or 'enclaves' of innovation?" Technovation 14 93-110

FiberHome, 2011, "Group introduction”, http://www.wri.com.cn/about/about.shtml

Freeman C, 1988, “Japan: a new national innovation system?”, in Technical Change and Economic Theory Eds G Dosi, C Freeman, R Nelson, G Silverberg, L Soete (Pinter, London) pp 330-348

Godin B, 2006, "The linear model of innovation: the historical construction of an analytical framework" Science, Technology and Human Values 31 639-667

Grayson L, 1993 Science Parks: An Experiment in High Technology Transfer Science Reference and Information Service, British Library, London

Guang C, 1995, "The population increases in East Lake High-tech Development Zone" Yangtze Daily 29 March, page 12 (in Chinese)

Haifeng W, 2005, "The number of development zones was reduced by 4813 , accounted from $70.1 \%$ of the total", Stockstar, http://finance.stockstar.com/ZH2005032301165280.shtml

Hall P, Breheny M, McQuaid R, Hart D, 1987 Western Sunrise: The Genesis and Growth of Britain's Major High Tech Corridor (Allen and Unwin, London)

Hansson F, Husted K, Vestergaard J, 2005, "Second generation science parks: from structural holes jockeys to social capital catalysts of the knowledge society" Technovation 25 1039-1049

Hendry C, Brown J, 2006, "Dynamics of clustering and performance in the UK opto-electronics industry" Regional Studies 40 707-725

Hendry C, Brown J, DeFillippi R, 2000, "Regional clustering of high technology-based firms: optoelectronics in three countries" Regional Studies 34 129-144

Hendry C, Brown J, DeFillippi R, Hassink R, 1999, "Industry clusters as commercial, knowledge and institutional networks: opto-electronics in six regions in the UK, USA and Germany", in Interfirm Networks, Organization and Industrial Competitiveness Ed. G Anna (Routledge, London) pp 151-184

Hendry C, Brown J, Ganter H D, Hilland S, 2003, "Facilitating innovation in opto-electronics in a national, global, and regional context" Environment and Planning C: Government and Policy $2153-70$

Hong W, 2008, "Decline of the center: the decentralizing process of knowledge transfer of Chinese universities from 1985 to 2004" Research Policy 37 580-595

Honggu L, 1993, "East Lake is going to make more preferencial policies and accelerate the construction of science town" Yangtze Daily 8 February, pages 85-86 (in Chinese)

Jefferson G, Hu A G Z, Guan X, Yu X, 2003, “Ownership, performance, and innovation in China's large- and medium-size industrial enterprise sector" China Economic Review 14 89-113

John M, Barry N, 1992, "How to reform a planned economy: lessons from China" Oxford Review of Economic Policy 8 130-143

Junpeng J, 2009, “The development of China's 'Optical Valley' and optoelectronic industry parks”, Baidu Space, http://hi.baidu.com/\%BD\%AA\%BE\%FC\%C5\%f4/blog/item/671f513ac5aad4e215cecbc9.html 
Keeble D E, 1989, "High-technology industry and regional development in Britain: the case of the Cambridge phenomenon" Environment and Planning C: Government and Policy 7 153-172

Kung S F, 1995 The Role of Science Parks in the Development of High Technology Industries, with Special Reference to Taiwan PhD thesis, Department of Geography, University of Cambridge, Cambridge

Luger M I, Goldstein H A, 1991 Technology in the Garden: Research Parks and Regional Economic Development (University of North Carolina Press, Chapel Hill, NC)

Lundvall B, 1985 Product Innovation and User-Producer Interaction, Industrial Development (Aalborg University Press, Aalborg)

Lundvall B, 1992 National Systems of Innovation: Towards A Theory of Innovation and Interactive Learning (Pinter, London)

Lundvall B, 2007, "National innovation system: analytical focusing device and policy learning tool", ITPS, Swedish Institute for Growth Policy Studies, Sweden

Massey D, Quintas P, Wield D, 1992 High Tech Fantasies: Science Parks in Society, Science and Space (Routledge, London)

Moore B, Spires R, 1983 The Experience of the Cambridge Science Park (OECD, Paris)

MOST, 2004, "TORCH Programme: I. Nature and purposes", Ministry of Science and Technology of the People's Republic of China, Beijing

Mothe J D, Paquet G, 1998 Local and Regional Systems of Innovation (Springer, Dordrecht)

National Research Database Center, 2011, "Employment and salary database", statistics database, http://edu.drcnet.com.cn/DRCNet.Edu.Web/

Naughton B, 1990, “China's experience with guidance planning” Journal of Comparative Economics $14743-767$

Nelson R, 1988, "Institutional supporting technological change in the United States", in Technical Change and Economic Theory Eds G Dosi, C Freeman, R Nelson, G Silverberg, L Soete (Pinter, London) pp 312-329

OECD, 2008 OECD Reviews of Innovation Policy: China (OECD, Paris)

O'Mara M P, 2005 Cities of Knowledge: Cold War Science and the Search for the Next Silicon Valley (Princeton University Press, Princeton, NJ)

OVC, Optics Valley of China

2007, "2006 statistics report of OVC", annual statistics, http://www.wehdz.gov.cn/jsp/zwgk/browser/ main.jsp?deptid=wehdz00004\&nodeid=wehdz00101 \&infotype=text

2009, "History and achievements", http://en.wehdz.gov.cn/structure/History/History

2010a, "Administration boundary map of OVC", http://www.wehdz.gov.cn/ structure/kg/ztgh/ztghzw_14544_1.htm

2010b, "The comprehensive planning map of OVC", http://www.wehdz.gov.cn/ structure/kg/ztgh/ztgh.htm

2011a, "Annual statistics report of East Lake High-tech Development Zone 2007", http://www.wehdz.gov.cn/jsp/zwgk/browser/content.jsp?id=382

2011b, “Annual statistics report of East Lake High-tech Development Zone 2008”, http://www.wehdz.gov.cn/jsp/zwgk/browser/content.jsp?id=383

People's Government of Wuhan, 2011, "East Lake New Technology Development Zone History Record", Wuhan Local Annals, http://www.whfz.gov.cn:8080/pub/dqwx/ delsz/ggkf/dslp/ dyz/200801/t20080101_19661.shtml

Perez C, Soete L, 1988, "Catching up in technology: entry barriers and windows of opportunity", in Technical Change and Economic Theory Ed. G Dosi (Pinter, London) pp 458-479

Phelps N A, 2008, "Cluster or capture: manufacturing FDI, external economies and agglomeration" Regional Studies 42 457-473

Phelps N A, 2009, "From branch plant economies to knowledge economies? Manufacturing industry, government policy, and economic development in Britain's old industrial regions" Environment and Planning C: Government and Policy 27 574-592

Phillimore J, Joseph R, 2003, "Science parks: a triumph of hype over experience?", in The International Handbook on Innovation Ed. L V Shavinina (Elsevier, London) pp 750-757 
Press K, 2006 A Life Cycle for Clusters? The Dynamics of Agglomeration, Change, and Adaption (Physica, Heidelberg)

Radosevic S, 2007, "National systems of innovation and entrepreneurship: in search of a missing link", Centre for the Study of Economic and Social Change in Europe, UCL School of Slavonic and East European Studies, London

Rui C, 2001, "Luo Qingquan requires to construct the Optical Valley down-to-earth" Wuhan Daily 6 January, page 3 (in Chinese)

Saxenian A, 1985, "The genesis of Silicon Valley", in Silicon Landscapes Eds P Hall, A Markusen (Allen and Unwin, Boston, MA) pp 20-34

Shangmin Y, 2010, "The ninth extension of YOFC target at the domestic broadband market", China Communication Industry Net, http://www.ccidcom.com/html/guanzhu/ 201011/07-127139.html

Shanla Y, 1993, "Development of East Lake into a first class science town" China Import Newspaper 28 December, pages 102-105 (in Chinese)

Shanla Y, 1994, "East Lake High-tech Development Zone is marching forward" Yangtze Daily 28 October, pages 13-14 (in Chinese)

Statistics Bureau of China, 2009, "Annual statistics of high-tech industries of China, 2009”, The Statistics Bureau of China, Beijing, http://www.stats.gov.cn/tjsj/qtsj/zgkjtjnj/2009/

Statistics Bureau of Hubei, 2009 Hubei Statistics Yearbook 2009 (China Statistics Publisher, Beijing)

Storper M, Venables A J, 2003, "Buzz: face-to-face contact and the urban economy", Centre for Economic Performance, London School of Economics and Political Science

STS, 2011, "The data base of China's main science and technology index", China Science and Technology Statistics, http://www.sts.org.cn/

Torch Center, 2001 A Decade of Data and Reports of the National High-tech Development Zone: 1991-2000 (Science and Technology Literature Publisher, Beijing)

Torch Center, 2008, "National High-tech zone of China", Ministry of Science and Technology, Beijing

Torch Center, 2009, "National science and technology industrial parks (STIPs)", Ministry of Science and Technology, Beijing

Vedovello C, 1997, "Science parks and university-industry interaction: geographical proximity between the agents as a driving force" Technovation 17 491-502

Vedovello C, 2000, "Science parks and university-industry links: a comparative analysis between a British and a Portuguese experience" International Journal of Services Technology and Management $1358-374$

Wan L, 1991, "Development of the East Lake High-tech Zone as Wuhan's 'special zone' "Yangtze Daily 9 June, pages 54-54 (in Chinese)

WEHDZ, 2005 Witness Wuhan. Optics Valley of China: 1984-2004 East Lake Wuhan High-tech Zone (Central Document Publisher, Beijing)

WEHDZ, 2010, “'East Lake future technology town' chosen to locate east of OVC”, East Lake Wuhan High-tech Zone, http://www.wehdz.gov.cn/structure/xw/yw/ywzw_16442_1.htm

Wei Y H D, 2010, "Beyond new regionalism, beyond global production networks: remaking the Sunan model, China" Environment and Planning C: Government and Policy 28 72-96

Wei Y H, Leung C K, 2005, "Development zones, foreign investment, and global city formation in Shanghai" Growth and Change 36 16-40

Westhead P, Storey D J, 1994 An Assessment of Firms Located On and Off Science Parks in the United Kindom: Main Report (HMSO, London)

Wuhan Party History Research Centre, 2009, "Create glory in the speed of light: the history of OVC", http://www. whds.org.cn/content.jsp?id=3744

Xinhua News Agency, 2010, "The number of state-level high-tech development zones has increased to 70”, http://finance.jrj.com.cn/2010/11/1915438605777.shtml (in Chinese)

Zhongguancun Science Park, 2010, "Comprehensive report on the development of high-tech industries in Zhongguancun Science Park, 2006", http://www.zgc.gov.cn/ document/20100608161139375488.pdf

Zhongliang W, 2011, "There are 84 state-level science parks in China now" Changzhou High-Tech Zone pages D3-D3 